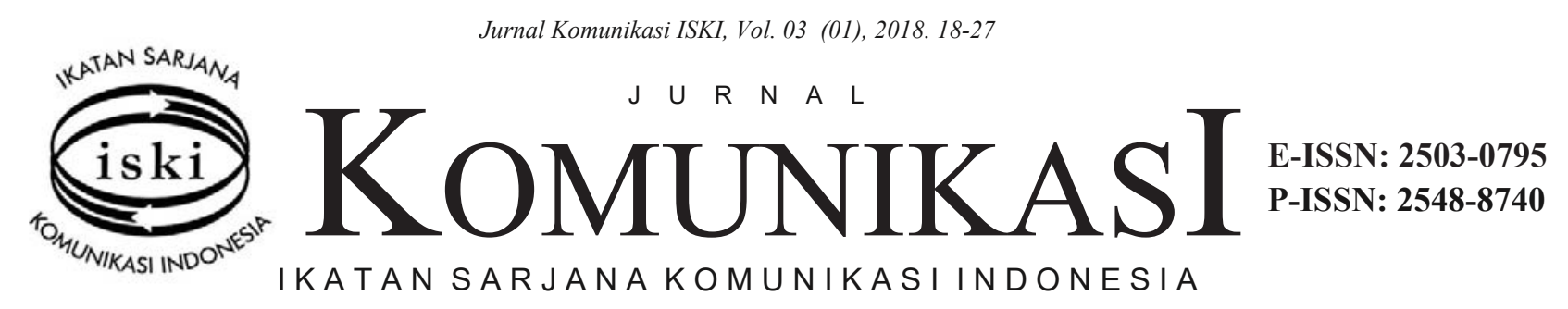

\title{
AirAsia Crisis Communications Strategies and Malaysia Airlines: A Content Analysis
}

\author{
http://dx.doi.org/10.25008/jkiski.v3i1.145 \\ Ni Ketut Dimar Warsihantari ${ }^{1}$ and I Gusti Ngurah Putra ${ }^{2}$ \\ 1,2 Universitas Gadjah Mada \\ Jl. Sosio-Yustitia, Bulaksumur, Yogyakarta 55281 - Indonesia \\ 1'gnputra@ugm.ac.id
}

\begin{abstract}
The aviation industry is one of the most vulnerable industrial sectors to the crisis. Failure to manage the crisis they face, it can threaten their lives. Therefore, managers of airline companies are required to have the ability to manage crisis and communicate in crisis situations. Crisis communication strategy becomes an important part in crisis management. This study uses content analysis of the crisis communication strategies used by AirAsia and Malaysia Airlines in their respective aircraft accidents on December 28, 2014 and March 8, 2014. This research found that both companies are fast enough to respond to crises, despite they use different strategies in response of the crisis. AirAsia emphasizes the use of apology without ignoring compensating, while Malaysia Airlines emphasizes compensation without ignoring apology.
\end{abstract}

Keywords: Crisis communication, Press releases, Aviation industry, Apology

\begin{abstract}
Abstrak
Dunia penerbangan merupakan salah satu sektor industri yang sangat rentan terserang krisis. Kegagalan dalam mengelola krisis yang mereka hadapi dapat mengancam kehidupan mereka. Oleh karena itu, para manajer pengelola perusahaan penerbangan dituntut untuk memiliki kemampuan dalam mengelola krisis dan berkomunikasi dalam situasi krisis. Strategi komunikasi krisis menjadi bagian penting yang dalam pengelolaan krisis. Penelitian ini dengan menggunakan analisis isi terhadap strategi komunikasi krisis yang digunakan AirAsia dan Malaysia Airlines dalam kecelakaan pesawat mereka yang terjadi masing-masing pada 28 Desember 2014 dan 8 Maret 2014. Riset ini menemukan bahwa kedua perusahaan cukup cepat dalam merespon krisis walau terdapat perbedaan dalam strategi mereka dalam merespon krisis. AirAsia lebih menekankan pada penggunan apologi tanpa mengabaikan kompensasi, sementara Malaysia Airlines lebih menekankan kompensasi tanpa mengabaikan apologi.
\end{abstract}

Kata Kunci: Komunikasi krisis, Siaran pers, Industri penerbangan, Pemintaan maaf

Copyright @ 2017 Ikatan Sarjana Komunikasi Indonesia. All rights reserved

\section{Introduction}

The aviation industry is one of the most vulnerable components of transportation to the crisis, mainly due to aviation safety as a result of an accident (Ray, 1999). Indeed, the crisis experienced by the aviation industry can be caused by various 
factors such as terrorism, financial or management failure and so on. Failure to manage the crisis can lead to corporate bankruptcy. The names of airlines in Indonesia such as Sempati Air, Boraq, Mandala, Adam Air and many others are now just memories. In Australia, Ansett, for example, as number two of the largest company after Qantas, also failed to manage its crisis, so it is now only a historical record (McDonald, 2005). In India, Kingfisher Airlines suffered a loss of about 1.5 billion dollars, causing employees to strike and forced to reduce the operation of its fleet (voaindonesia.com, 2012). Similar financial crisis is also experienced by British Airways and United Airlines (kompas.com, 2008 and viva.co.id, 2010).

The International Air Transport Association (IATA) reports that there are 12 fatal aviation accidents with 641 deaths during 2014. This figure is lower than the five-year period (2009-2013) which reached 19 fatal accidents with 517 deaths per year (IATA, 2014). Although the level of having lost control in-flight decreased to 6 accidents by 2014 , this figure is worth considering. The three main causes of plane crashes by Airplane Crash Statistic 2016 are pilot error (53\%), mechanical failure (20\%) and weather (12\%) (Statistic Brain Research Institute, 2016).

AirAsia and Malaysia Airlines are the two Malaysian airlines that experienced a crisis in 2014. The plane that crashed was AirAsia with flight code QZ8501 on flights from Surabaya to Singapore and Malaysia Airlines with the MH370 flight code on its way from Kuala Lumpur to Beijing. No survived in the two accidents.

Both accidents have come under intense scrutiny by local and international media over the past two years. Some media are also interested to compare both cases of accidents due to the value of the proximity to time or type of accident. The case of AirAsia and Malaysia Airlines which at first sight seem identical to have differences in the causes of accidents and public reaction caused (Cbsnews.com, 2014). The daily.com article also stated that AirAsia with its CEO Tonny Fernandes responded more quickly in response to the crisis than Malaysia Airlines (Allen, 2015). This difference of public reaction is the basis for examining how AirAsia and Malaysia Airlines are implementing their crisis communication strategy after the accident. In addition, the difference in the ownership status of the company, Air Asia is a privately owned company and Malaysia Airlines is a state-owned airline allegedly influencing the response shown by both companies. The interesting thing is also to compare these two accidents happened at the adjacent time.

Media coverage in crisis situations can influence stakeholder views on AirAsia and Malaysia Airlines reputation. After all, stakeholders interact with the media in their daily lives and each media is entitled to determine any information that will be consumed by the public. It is therefore important for both organizations to communicate to the media about the organizational attitudes and crisis communication measures that are or have been done. Other internal information sources such as organizational owner statements, internal documents, fact sheets usually also appear on the website as supporting data. The research wants to see how the crisis communications strategy carried out by AirAsia and Malaysia Airlines through the use of press releases. This information is a source of news for the media in constructing the news.

Taylor and Perry (2005) revealed that more than $80 \%$ of organizations experiencing crisis upload news release as a source of information through their official website. This high percentage indicates that the press release is still the preferred communication tactic favored by the organization.

This paper is structured on the basis of this analysis comparing the crisis communication strategies used by AirAsia and Malaysia Airlines following the aircraft crashes through press releases on airasia.com and malaysiaairlines.com sites for the period of December 28, 2014 - March 4, 2015 and March 8, 2014 - August 6, 2015.

\section{Theoretical Framework}

Research on crisis communications strategies comes in many variations. The variation can be in the type of case raised and the method used. The comparative content analysis of the British Petroleum (BP) and Tokyo Electric Power Company (TEPCO) communications strategy by Abramenka (2013) becomes one of the references in this study. This study attempts to compare crisis communication strategies used by both organizations 
through press releases and facebook and twitter information. The two main theories used to dissect the case are the theme of crisis messages (trust, collaboration, commitment and interactivity) and crisis response strategies which is Situational Crisis Communication Theory (denial, diminish, rebuild and bolstering). The results of this study indicate that BP predominantly emphasizes its commitment to overcome the crisis that occurs while TEPCO often uses more on combination of message commitment and collaboration. In addition, it can be seen that some of the press releases issued by both organizations contain apology message strategy and commitment to minimize the impact of the crisis as soon as possible.

Analysis of the content of crisis communication strategies has also been made to the financial crisis of General Motors (GM) with SCCT from Coomb as the basic framework of the theory. In accordance with the method of content analysis, Cooley and Cooley (2011) coded GM's official statements in the form of press releases, press conferences, CEO blogs, CEO speeches, YouTube pages and presidential speech from General Motors. The finding of this research is that GM most often uses diminish strategies and in accordance with the recommendations of crisis communication strategies described in SCCT theory.

In the aviation industry crisis, Cowden and Sellnow (2002) are interested in researching Northwest Airlines (NWA) advertising as a medium of crisis communications. Specifically, this study analyzes the use of image restoration strategies (Benoit 1995) in Northwest Airlines commercials during a pilot case in 1998. Cowden and Sellnow found that advertising used by the NWA as a proactive attempt is to dismiss pilots but unfortunately fail to maintain the confidence of the investors and do not consider the history of relationships with employees. Another important point is that the actual ad campaign can integrate the image restoration strategies as part of the organization's crisis management plan and provide important information for internal or external stakeholders.

Situational Crisis Communication Theory (SCCT) provides a working platform for crisis managers to adapt crisis communications strategies to the level of crisis responsibility and reputation threats posed by a crisis. The adverse impact of the crisis on reputation leads management to the selection of communication strategies to respond to crises (Coombs, 2006: 243). The threat of reputation is defined as how much damage the crisis brings if the organization does not take action to respond to the crisis. Reputation threats can be caused by initial crisis responsibility, crisis history and reputation before a crisis.

SCCT has developed a crisis assessment system consisting of two stages: assessment of the type of crisis and the threat of crisis to reputation (Coomb, 2007). This type of crisis is divided into three clusters: (1) victim, which is the type of crisis in which the organization becomes the victim of crisis such as natural disaster, rumors, workplace violence, malevolence toward the organization; (2) accidental, that is the organization minimizes responsibility because the crisis is accidental or unintentional such as challenges, technical error, and product harm; (3) preventable crisis, which is a crisis that allows stakeholders to fully believe that the organization should be responsible as human error, organizational misdeed, management misconduct, organizational misdeed with injuries (Coombs, 2007: 168). Challenges in this case means stakeholders claim that the organization is doing its business in an inappropriate ways (Coombs, 2007b).

The second stage is a threat to the reputation of the organization judged from two important factors concerning stakeholder perceptions of the crisis that is the history of organizational crisis and negative reputation that had previously been owned (Coombs, 2007). The high value of these two factors indicates that the organization assumes a great responsibility for the crisis.

The results of the two previous assessment phases will help the organization to choose the right communication strategy to respond to the crisis. According to Coombs (2007) the crisis communication strategy has three goals related to reputation protection -(1) forming crisis attributes, (2) changing the perception of the organization about the crisis and (3) reducing the negative effects of crisis. SCCT offers a communication strategy consisting of four groups which are then classified into two categories: primary and secondary 
communication strategies. The secondary strategy serves to complement 3 strategic and strategic strategies if used by reputable organizations in the past (Coombs, 2010).

Coombs (2010: 104) summarizes some important recommendations regarding the use of SCCT crisis communication strategies. The following is a table that will explain how the crisis manager should align the type of crisis faced with the communication strategy by having taken into account the history of the organizational crisis. Then it can be seen also that each crisis raises different levels of responsibility for the organization. Different crisis subtypes in the same type of crisis can give rise to different strategy recommendations.

Table 1 SCCT Response Strategy Recommendations

\begin{tabular}{|c|c|c|c|}
\hline Crisis Types & $\begin{array}{l}\text { Crisis } \\
\text { subtype }\end{array}$ & $\begin{array}{l}\text { History of } \\
\text { Org. Crisis }\end{array}$ & $\begin{array}{l}\text { Recommendations } \\
\text { Strategy }\end{array}$ \\
\hline \multirow{2}{*}{$\begin{array}{l}\text { Victim cluster } \\
\text { (low } \\
\text { responsibility) }\end{array}$} & & $\begin{array}{l}\text { Similar crisis } \\
\text { and bad } \\
\text { reputation }\end{array}$ & Diminish strategy \\
\hline & Rumor & & Denial strategy \\
\hline \multirow{4}{*}{$\begin{array}{l}\text { Accident } \\
\text { cluster } \\
\text { (moderate } \\
\text { responsibility) }\end{array}$} & & $\begin{array}{l}\text { No similar } \\
\text { crisis and no } \\
\text { bad reputation }\end{array}$ & Diminish strategy \\
\hline & & 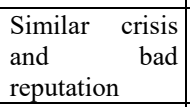 & Rebuild Strategy \\
\hline & \multirow[b]{2}{*}{ Challenge } & $\begin{array}{l}\text { Inappropriate } \\
\text { challenge }\end{array}$ & Denial Strategy \\
\hline & & $\begin{array}{l}\text { organization } \\
\text { deserves a } \\
\text { challenge }\end{array}$ & $\begin{array}{l}\text { Rebuild stratgey } \\
\text { then corrective } \\
\text { action }\end{array}$ \\
\hline $\begin{array}{l}\text { Preventable } \\
\text { cluster } \\
\text { (high } \\
\text { responsibility) }\end{array}$ & & & Rebuild Strategy \\
\hline
\end{tabular}

Adapted from Coombs (2010:103-104)

As a general recommendation, Coombs (2010) suggests that reinforcing strategies or secondary crisis strategies are used to support other strategies. This strategy is only used if the organization has a good achievement in the past. A victim strategy can be used only if the organization experiences a victim cluster type of crisis. The use of a combination of denial strategies with diminish or rebuild strategies is not recommended. However, diminishing and rebuilding strategies can be combined with each other.

Coomb (2010: 159) in his theory also offers seven categories of crisis communication strategies that are then sorted from the defensive to accommodative. The seven communication strategies have been used as the theoretical foundations in comparative studies of messages in print media related to the food communication crisis experienced by South Korea and the United States (Wertz and Kim, 2010). These seven strategies used are to see the public perception of communication strategy used by the organization. The seven crisis communication strategies are: (1) attack the accuser (attacking parties who say the crisis occurred including threats such as courts); (2) denial (claiming no crisis); (3) excuse (minimizes organizational responsibility for crisis due to accident and beyond the limits of organizational capability); (4) justification (minimizing the personalized damage caused by the crisis); (5) ingratiation (reminding stakeholders of the good deeds of the organization in the past); (6) corrective action (to repair the damage caused by the crisis, or even prevent the recurrence of the crisis); (7) full apology (fully responsible for crisis and apologize to stakeholders including compensation).

\section{- Conceptual framework}

The concept of crisis communication strategy to be used in this research is the concept of SCCT Crisis Response Strategies (Coombs, 2007b: 140) consisting of four groups namely (1) denial posture, (2) diminish posture, (3) rebuild posture (all three are classified into in the primary strategy) and (4) bolstering posture (secondary strategy). Denial consists of attack the accuser, denial (organization asserts no crisis), and scapegoating (blaming groups of people or groups outside the organization). Diminish consists of excuses (minimizing responsibility for crises by reason of no ill-will or intent or beyond the limits of organizational capability) and justification (minimizing the personalized damage caused by the crisis). Rebuild consists of compensation and apology (fully responsible for the crisis and apologizes to stakeholders). Bolstering consists of reminders (telling stakeholders about past organizational good deeds), ingratiation (pleasing stakeholders or reminding the good of the organization) and victim (reminding stakeholders that organizations are also victims of crisis). 
Based on the conceptual framework, the unit of analysis and categorization used are as follows:

Table 2: Analysis Unit and Categorization

\begin{tabular}{|c|c|c|}
\hline Analysis uni & & ategory \\
\hline Crisis comm & nication strateg & of SCCT: \\
\hline & $\begin{array}{l}\text { - Denial } \\
\text { Posture }=1\end{array}$ & $\begin{array}{l}\text { - } \text { Attack the } \\
\text { accuser }=\mathrm{a} \\
\text { - Denial = b } \\
\text { - Scapegoat = c }\end{array}$ \\
\hline $\begin{array}{l}\text { - Primary } \\
\text { Crisis } \\
\text { Response }\end{array}$ & $\begin{array}{l}\text { - } \text { Diminish } \\
\text { Posture }=2\end{array}$ & $\begin{array}{l}\text { - Excuse }=\mathrm{a} \\
\text { - Justification = } \mathrm{b}\end{array}$ \\
\hline & $\begin{array}{l}\text { - Rebuild } \\
\text { Posture }=3\end{array}$ & $\begin{array}{l}\text { - } \text { Compensation = } \mathrm{a} \\
\text { - Apology }=\mathrm{b}\end{array}$ \\
\hline $\begin{array}{l}\text { - Secondary } \\
\text { Crisis } \\
\text { Response } \\
\text { Strategies }\end{array}$ & $\begin{array}{l}- \text { Bolstering } \\
\text { Posture }=4\end{array}$ & $\begin{array}{l}\text { - Reminder }=\mathrm{a} \\
\text { - Ingratiation }=\mathrm{b} \\
\text { - Victimage }=\mathrm{c}\end{array}$ \\
\hline
\end{tabular}

\section{Material and Methodology}

This research uses content analysis method to compare, classify and describe crisis communication strategy chosen by AirAsia and Malaysia Airlines. Both of these flight cases were selected primarily because of their incidence in the not too distant future and also to see if there were differences in response by private airlines and government owned airlines. The selected object was press release on airasia.com and malaysiaairlines.com official sites. Given the amount of text that is not so much, all the number of press releases as much as 135 texts consisting of 74 texts on malaysiaairlines.com website and 61 texts on airasia.com site serve as the object of analysis. The AirAsia press release under study is in the period of December 28, 2014 to March 4, 2015. While the Malaysian Airlines press release under study is within the period of March 8, 2014 to August 6, 2015. Press releases issued by the two airlines are available on airasia.com and malaysiaairlines.com. On malaysiaairlines.com website, the press room menu on the corporate info tab contains all press releases issued by Malaysian Airlines. The researcher then selects "MH370: Media Statement" to collect all press releases related only to the $\mathrm{MH} 370$ case. While the AirAsia creates a special official site that is http://qz8501.airasia.com/index.html to upload the entire press release associated with the accident QZ8501. This site is linked to airasia.com/my's official site operated by AirAsia Berhad based in Kuala Lumpur, Malaysia. This study has limitations because it only utilizes press release uploaded on the website, so it is unable to reach press releases issued through other mechanisms such as directly sent to the mass media.

Data analysis is done by descriptive statistical analysis technique that is frequency distribution. Descriptive statistics relate to the application of statistical methods for collecting, processing, presenting, and analyzing quantitative data descriptively. Frequency distribution analysis is used to derive numbers which are responses from different analytical units and are expressed in percentages.

\section{Result and Discussion}

The texts (press releases) that are the object of this study have an amount equal to the population. The small number of population that is considered by all the population to be a sample or research using a census that uses the entire population as the object studied. Details of the press release are as follows:

Table 3: Volume of Press Releases

\begin{tabular}{|l|c|c|}
\hline Organisasi & Period & $\begin{array}{c}\text { Number of } \\
\text { text }\end{array}$ \\
\hline AirAsia & $\begin{array}{c}\text { 28 December } 2014 \\
-4 \text { March } 2015\end{array}$ & 61 texts \\
\hline Malaysia & $\begin{array}{c}\text { March } 2014- \\
6 \text { August } \\
\text { Airlines }\end{array}$ & 74 texts \\
\hline Total & & $\mathbf{1 3 5}$ \\
\hline
\end{tabular}

The use of crisis communication strategies in the internet cannot be separated from the element of speed, because the internet provides instant access indefinitely and in places. This speed is about how responsive the organization responds to the crisis being faced. AirAsia and Malaysia Airlines are said to be quick in responding to the crisis if within the first 48 hours since the crisis they have communicated the crisis to the public in this case through press release. The following data shows the number of responses made by AirAsia and Malaysia Airlines for 48 hours after the crisis. 


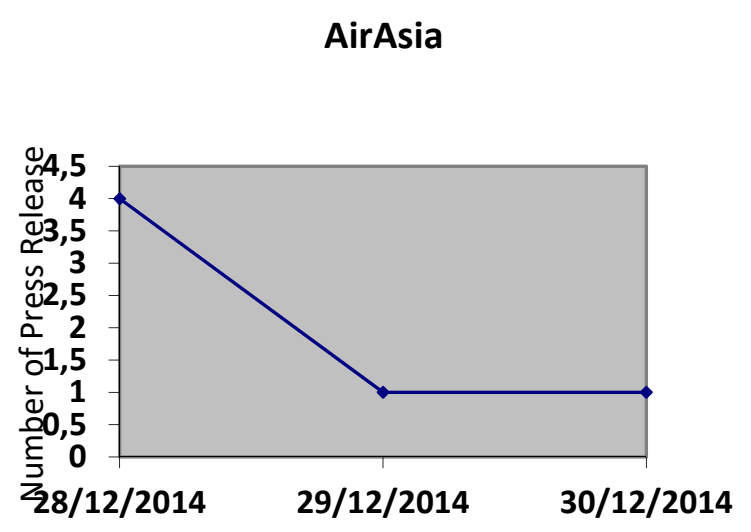

First 48 hours

Figure 1 Number of Response by AirAsia

Malaysia Airlines

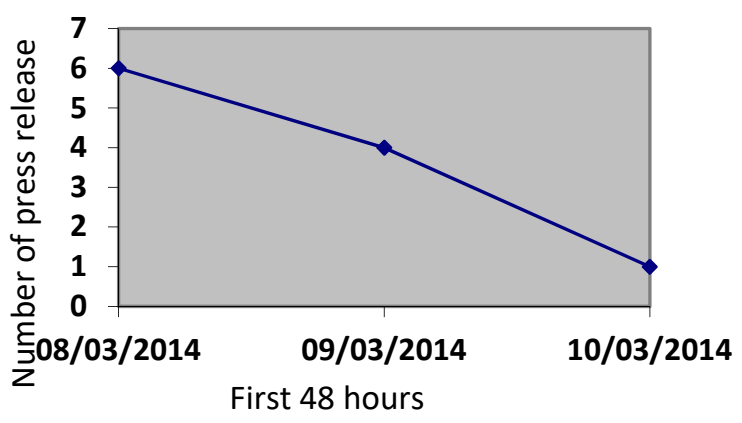

Figure 2 Number of Response by Malaysia Airlines

AirAsia and Malaysia Airlines capitalized on their first 48 hours by communicating the crisis to the public. Both organizations appear to communicate the crisis on the first day of the crisis with the highest number of press releases compared to the days after. AirAsia issued 4 pieces of press release on the first day and one day at a later date while Malaysia Airlines issued 6 press releases on the first day, 4 pieces a day later and 1 on the third day. Quantitatively, Malaysia Airlines is more vigorous response to the crisis. The rapid development of information also indicates that the organization acts quickly in response to the crisis. The following will explain the comparison of information content within the first 48 hours between AirAsia and Malaysia Airlines.
Hours after the crisis AirAsia announced the QZ8501 aircraft had lost contact with ATC Surabaya early in the morning at local time. Other information that follows are airplane identity details, aircraft maintenance status, number and citizenship of passengers, crew, search and rescue process, as well as instructional issues, such as emergency call center notification, periodic information updates on airasia.com website and warning to media crews not to call emergency call centers which is devoted to the victims' families. Malaysia Airlines is also doing the same thing-- only Malaysia provides connecting links containing information related to the crisis coming from the official website of Malaysian Government. The information previously mentioned is a combination of adjusting and instructing information (Sturges, 1994 \& Coombs, 2011). These two acts of granting of information are reasonably granted by AirAsia and Malaysia Airlines in the early hours of the crisis for the purpose of public security (Coombs, 2010: 61).

From the analysis of the press release, there are different response strategies used by both organizations during the first 48 hours. Here is a table that shows the difference.

Table 4 Frequency of Use of Response Strategy

(First 48 hours)

\begin{tabular}{|c|c|c|}
\hline Organization & $\begin{array}{c}\text { Primary } \\
\text { Strategy }\end{array}$ & $\begin{array}{c}\text { Secondary } \\
\text { Strategy }\end{array}$ \\
\hline \multirow{4}{*}{ AirAsia } & Apology (3) & \multirow{2}{*}{ Non (6) } \\
\cline { 2 - 2 } & $\begin{array}{c}\text { Excuse-Apology } \\
(2)\end{array}$ & \\
\cline { 2 - 2 } & $\begin{array}{c}\text { Compensation- } \\
\text { Apology (1) }\end{array}$ & \\
\hline Total & $\mathbf{6}$ & $\mathbf{6}$ \\
\hline \multirow{3}{*}{$\begin{array}{c}\text { Malaysia } \\
\text { Airlines }\end{array}$} & $\begin{array}{c}\text { Compensation (6) } \\
(1)\end{array}$ \\
\cline { 2 - 2 } & Apology (1) & Non (10) \\
\cline { 2 - 3 } Total & Non (4) & $\mathbf{1 1}$ \\
\hline
\end{tabular}

Source: processed from the primary data of researchers

Malaysia Airlines is focusing its compensation strategy on its early handling of the crisis compared to AirAsia. Compensation provided by Malaysia Airlines is the cost of the victim's family flights and 
all travel needs to the location of the MH370 aircraft, travel, accommodation, foods and funding for basic needs.

In addition, the closeness of the organization to the mainstream public in this case is the victim's family. On the first day of the crisis, AirAsia's management represented by Sunu Widyatmoko along with the Governor of East Java, Basarnas (National Search and Rescue Agency), representative of Angkasa Pura 1 met with the families of victims in Surabaya to deliver the latest information about the crisis and commitment in serving their needs during the crisis. Here are excerpts of the phrase in the press release of AirAsia issued at 11:40 PM on December 28, 2014.

Earlier in Surabaya, the management of AirAsia along with the Governor of East Java, the Airport Authority of Indonesia, the Airport Operator (Angkasa Pura I) met with the members of the families to update them on the latest developments and reconfirmed their commitment to provide assistance in every possible way.

Sunu Widyatmoko also expressed his sympathy for the families of the victims. Meanwhile, Malaysia Airlines representatives only met directly with the victims' families in Beijing on the second post-crisis day on March 9, 2014. On the 2nd day of the crisis Ahmad Jauhari Yahya, Group Chief Executive Officer of MAS appeared to provide adjusting information as Sunu Widyatmoko. The direct presence of management in the family of the victims and direct sympathy statements is included in the adjusting information that serves to help the victim's family handle his psychological problems. In addition, the presence of management figures in the midst of crisis and a source of crisis information is clear evidence that organizations are actively involved in crisis management (Holladay, 2009)

Factually, AirAsia is quicker to locate the wreckage than Malaysia Airlines. Malaysia Airlines along with the Singapore, and Vietnam teams stated that his team failed to find the MH370 airplane flakes on the first day of the crisis. Meanwhile, AirAsia can only deliver the location of the discovery of plane flakes on the 3rd day of the crisis. Nevertheless, AirAsia successfully confirmed the location of the
QZ8501 splinter plane in the Karimata Strait via Basarnas.

This significant finding became the starting point for AirAsia to search for the bodies of victims who were even found the next day. This shows that AirAsia managed to locate the crash site within 48 hours. The AirAsia information cycle is automatically faster than Malaysia Airlines.

Things that need to be underlined in this point is the speed of response AirAsia and Malaysia Airlines is greatly influenced by natural factors. As it is known, the location of the fall of AirAsia aircraft is relatively easier compared to $\mathrm{MH} 370$. The location of the fall of MH370 is a very deep water area in the Indian Ocean while QZ8501 falls in a waters area not more than a few hundred feet deep. In addition the search area on the MH370 is wider than the QZ8501. Like an analyst quoted by CNN,

"It will not surprise me if this airplane is found in the next 12 hours of daylight, because they know it is 150 feet deep as opposed to 10- or 20,000 feet deep in the Indian Ocean. "(Pearson, 2014)

AirAsia benefits from natural factors and it is this condition that allows it to respond to the crisis faster than Malaysia Airlines. The impact is AirAsia has many new facts so as to present more progressive information.

Although in quantity, Malaysia Airlines is more aggressive in the communication with public, AirAsia provides more progressive information compared to Malaysia Airlines. But of course, this difference should be linked to the natural factors being faced by AirAsia and Malaysia Airlines. On the day of the crisis, Sunu Widyatmoko as AirAsia's management representative along with his crisis partner went directly to the crisis and met with the families of the victims while Malaysia Airlines, represented by Ahmad Jauhari Yahya, met directly with the families of victims in Beijing on the second day of the crisis. It is very clear that AirAsia's information movement is faster than Malaysia Airlines. With the discovery of the plane crash site on the 3rd day of the not-too-deep waters, AirAsia subsequently shifted its focus to the search for the bodies of the victims of QZ8501. Meanwhile, Malaysia Airlines has not managed to locate the 
crash site that initially fell in the Indian Ocean, so the information appears to have stalled at the point of search for the aircraft's location.

Organizational consistency in crisis-related communications is important for the public who are experiencing information gaps. The following is a graph depicting the intensity of crisis communications the two organizations which are conducting each month from the beginning of the crisis until the last time the organization issues a press release.

\section{Crisis Communication Intensity}

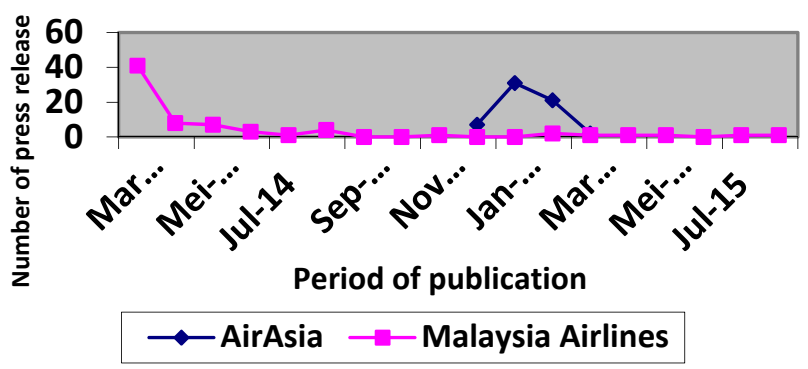

Figure 3 Crisis Communication Intensity

AirAsia spent four months to communicate the crisis while Malaysia Airlines spent 18 months. This happens because the conditions experienced by the two organizations are different. AirAsia and its partners in crisis quickly managed to find the wreckage of the plane and the body of the victim MH370. On the other hand Malaysia Airlines' hard work along with several countries and related agencies found no significant results although in the end the flakes on Reunion Island have been confirmed by Malaysia and related partners stating that it is really part of the MH370 aircraft wreckage.

Total number of press release issued by AirAsia is 61 units while Malaysia Airlines is 74 units. It can also be seen that the intensity of crisis communications conducted by Malaysia Airlines tends to decline from the first month of the crisis, while the communication crisis made by AirAsia tends to form an upward curve with the highest point in the second month of crisis.

The speed in responding to crises and response strategies employed by both firms may be influenced, among others, there is considerable awareness among both airlines managers to promptly provide certainty to the public about the status of the airlines' aircraft. That the information about the existence of the two planes is indeed not obviously understandable because of the absence of factual basis about the existence of the two planes. In the end, the AirAsia plane was found in relatively fast time, while the Malaysian Airlines plane is still a mystery. The speed of discovery of AirAsia aircraft helps AirAsia airlines in running crisis communication strategy. Conversely, it does not happen with Malaysia Airlines.

The choice of strategies that emphasize compensation that Malaysia Airlines is more emphasized as it may be influenced by airline ownership. Malaysia Airlines, which is Malaysia's pride airline, prioritizes reputation more than efficiency. For AirAsia, as a privately owned airline company, the efficiency factor for profitability may be an important consideration rather than direct compensation, AirAsia insists on apology. Indeed, these two airline companies cannot ignore the aspect of compensation.

\section{Conclusion}

Both Air Asia and Malaysia Airlines quickly responded to the crisis-related events of their flight accidents despite the plain uncertainty of the plane. They immediately issued a press release to respond to their situation so that the public immediately knew what was going on. The speed in responding to this indicates that both companies recognize there is a problem that they are facing. Both airlines do use different response strategies. Air Asia places more emphasis on apology by not neglecting the compensation to the victimized public. Malaysia Airlines further highlight the provision of compensation without forgetting the aspect of apology. Until now, both airlines are still able to operate normally, although Malaysia Airlines experiences a greater reputation crisis than AirAsia.

This study focuses only on the analysis of press releases as one of the tactics employed by companies in responding to the crisis. Therefore, there are still many research opportunities that can be done such as by looking at other tactics that are used in responding to the crisis as well. In addition, other research can 
also be done to compare the content of the press release with the news that appears in the mass media.

\section{References}

Abramenka, Viktoryia. (2013). Content Analysis of British Petroleum and Tokyo Electric Power Company's Crisis Communication Messages: Comparative Analysis of Crisis Communication Strategies. Grand Valley State University Masters Theses. Paper 55. Oai:scholarworks.gvsu.edu:theses-1054.

Allen, Kevin. (2015). Comparing Malaysia Airlines and AirAsia's crisis responses. Retrieved from:

http://www.prdaily.com/Main/Articles/Compa ring_Malaysia_Airlines_and_AirAsias_crisis re_17863

Benoit, W. L. (1995). Account, Excuses, and Apologies: A Theory of Image Restoration Strategy. Albany: State University of New York Press.

Cooley, S.C. dan Asya Besova Cooley. (2011). An Examination of The Situational Crisis Communication Theory Through The General Motors Bankruptcy. Journal of Media and Communication Studies Vol. 3(6) pp. 203-211. ISSN 2141-2545.

Coombs, W. T. (2006). The protective powers of crisis response strategies: Managing reputational assets during a crisis. Journal of promotion management, 12(3-4), 241-260. DOI:10.1300/J057v12n03_13.

Coombs, W. T. (2007). Protecting Organization Reputations During a Crisis: The Development and Application of Situational Crisis Communication Theory. Corporate Reputation Review, Vol. 10:163. DOI: 10.1057/palgrave.crr. 1550049

Coombs, W. T. (2010). Crisis Management: A Communicative Approach, In Botan C. \& Hazleton V. (Ed.) Public Relations Theory II. Mahaw, New Jersey: Lawrence Erlbaum Associates

Coombs, W. T., \& Holladay, S. J. (2007). The negative communication dynamic: Exploring the impact of stakeholder on behavioral intentions. Journal of Communication
Management, 11: 300-312. DOI: http://dx.doi.org/10.1108/1363254071084391 3.

Coombs, W. T. dan Holladay, S.J. (2010). The Handbook of Crisis Communication. Malden, MA: Wiley-Blackwell

Coombs, W. T., \& Holladay, S. J. (Eds.). (2011). The Handbook of Crisis Communication (Vol. 22). UK: John Wiley \& Sons.

Cowden, Kimberly dan Timotthy L. Sellnow. (2002). Issues Advertising as Crisis Communication: Northwest Airlines' Use of Image Restoration Strategies During the 1998 Pilot's Strike. Journal of Business Communication 39:193. DOI: $10.1177 / 002194360203900203$.

Csbsnews.com. (2014). How does AirAsia Flight 8501 compare to Malaysia Airlines Flight 370?". Retrieved from http://www.cbsnews.com/news/airasia-flight8501-compared-to-malaysia-airlines-flight$370 \%$

International Air Transport Association. April, 2015. Safety Report 2014. Montreal-Geneva. Retrieved from: http://www.iata.org/publications/Documents/i ata-safety-report-2014.pdf.

Kompas.com. 12 Desember 2008. Hadapi Krisis, United Airlines-Continental Airlines Bermitra. Retrieved from http://bisniskeuangan.kompas.com/read/2008 /12/12/12244924/Hadapi.Krisis..United.Airli nes-Continental.Airlines.

Komite Nasional Keselamatan Transportasi: Aircraft Accident Investigation Report. (2015). Retrieved from http://kemhubri.dephub.go.id/knkt/ntsc_aviati on/aaic.

McDonald, L. (2005). Perceiving is believing: How consumers attributions about the causes of the Ansett airlines' safety crisis impacted outcomes. Asia Pacific Public Relations Journal, Vol. 6(2), 1-13.

Nationalgeographic.co.id. 2 Desember 2015. Hasil Investigasi KNKT Ungkap Penyebab Kecelakaan Pesawat Air Asia QZ8501. Retrieved from http://nationalgeographic.co.id/berita/2015/12 
/hasil-investigasi-knkt-ungkap-penyebabkecelakaan-pesawat-air-asia-qz8501.

Ray, Sally J. (1999). Strategic Communication in Crisis Management: Lesson from the Airline Industry. Westport, Connecticut: Quorum Book.

-Sturges, David L. (1994). Communicating through crisis: A Strategy for Organizational Survival. Management Communication Quarterly. Thousand Oaks, CA: Sage Publications.

Statistic Brain Research Institute. (2016). Airplane Crash Statistic". Retrieved from http://www.statisticbrain.com/airplane-crashstatistics/.

Taylor, Maureen and Danielle C. Perry. (2005). Diffusion of traditional and new media tactics in crisis communication. Public Relations Review 31:209-217. DOI:10.1016/j.pubrev.2005.02.018.
Tempo.co. 28 Maret 2015. Sejarah Hari Ini: Garuda Indonesia Dibajak Teroris. Retrieved from https://m.tempo.co/read/news/2015/03/28/115 653505/sejarah-hari-ini-garuda-indonesiadibajak-teroris.

Tempo.co. 16 Maret 2016. Puing di Pulau Reunion Diragukan Milik Pesawat MH370. Retrieved from

https://m.tempo.co/read/news/2016/03/16/118 754234/puing-di-pulau-reunion-diragukanmilik-pesawat-mh370.

Viva.co.id. 20 Maret 2010. Kru Maskapai British Airways Mogok Kerja. Retrieved form http://dunia.news.viva.co.id/news/read/13785 7-kru-maskapai-british-airways-mogok-kerja.

Voaindonesia.com. 29 Oktober 2012. Maskapai Penerbangan India Dilanda Krisis Keuangan. Retrieved from: http://www.voaindonesia.com/a/maskapaipenerbangan-india-dilanda-krisiskeuangan/1534880.html 